\title{
GREENHOUSE GAS EMISSIONS CAUSED BY FARM MANURE MANAGEMENT IN LATVIA
}

\author{
Laima Berzina, Juris Priekulis, Aivars Aboltins, Olga Frolova \\ Latvia University of Life Sciences and Technologies, Latvia \\ laima.berzina@1lu.lv, juris.priekulis@1lu.lv, aivars.aboltins@inbox.lv, olga.frolova@1lu.lv
}

\begin{abstract}
The article discusses the effect of farm manure management on emissions of greenhouse gases or GHG. The Latvian GHG emission mandatory data for the time period from 2000 to 2017 have been used for the research. It has been stated that in animal breeding $73 \%$ of the total GHG emissions are related to the animal digestive tract and only $27 \%$ - to management of farm manure. Besides, the direct GHG emissions influenced by farm manure collection, storage and application technologies comprise only $13 \%$ of the total amount of GHG emissions from animal breeding, but $6 \%$ of emissions are created by working farm manure into the ground, $5 \%$ - from usage of pastures and $3 \%$ of the total emissions are indirect farm manure management emissions. Emissions caused by farm manure management from 2000 to 2017 in Latvia have increased by $3.7 \%$. It has been mainly influenced by the increasing number of beef cattle as well as by transition to more up-dated animal breeding technologies involving production of liquid manure. Using the present GHG emissions calculation method it is not possible to prognosticate reduction of these emissions. Therefore, it is necessary to implement the emission reduction measures described in special literature, for instance, addition of bacteriological or chemical additives to liquid manure, and these measures should be included in the methods of calculation of GHG emissions.
\end{abstract}

Keywords: farm manure, GHG emissions, animals, management.

\section{Introduction}

In Latvia there are favourable climatic conditions for development of animal breeding. In accordance with the information of the Central Statistical Bureau of the Republic of Latvia in 2017 there were 405800 cattle registered in the country, including 150400 milk cows [1;2].

Therefore, the present milk supply reaches $144 \%$, but beef - $192 \%$ [1;2].

Similarly, good results have been obtained also in poultry farming (egg supply $166 \%$ ), but also sheep breeding and goat breeding are considered to be perspective branches of agriculture.

In recent years great attention has been paid to improvement of management of the by-product of animal breeding - farm manure. At all largest barns farm manure storages are installed. The technologies of working farm manure into the ground are developed. Approximately $30 \%$ of the produced manure is used for production of biogas. However, the increase of GHG (greenhouse gas) emissions caused by animal breeding raises doubts as it contributes to global warming of the earth. Therefore, all EU countries are required to reduce the total amount of these emissions at least by $40 \%$ till 2030, but up to 2050 the reduction of GHG emissions should be in the amount of 80-95\% compared to 1990 [3]. For this purpose, in compliance with the Regulations No. 217 of the Cabinet of Ministers „Regulations on the national inventory system of greenhouse gas emission units” [4] every year in Latvia information should be summarised on the possible GHG emissions caused by different economic activities; it has been done since 1990.

Though, the previous inventory data show that the total amounts of these emissions in the country do not reduce, but they increase with every year. If, for instance, in 2000 these amounts reached $2248.80 \mathrm{kt} \mathrm{CO}_{2}$ equivalents, in 2017 - already $2782.32 \mathrm{kt} \mathrm{CO}_{2}$ equivalents, i.e. the increase reached $23.7 \%$. Still, the part of GHG emissions caused by farm manure management is comparatively small. For instance, in 2000 it was $13.5 \%$, but in $2007-11.5 \%$ of the total emissions. Nevertheless, the increase of farm manure management caused emissions in these years has been from 308.58 to $320.05 \mathrm{kt} \mathrm{CO}_{2}$ equivalents or by $3.7 \%$. Therefore, the aim of the present research is to specify the existing situation in the country in the sphere of GHG emissions as well as to evaluate the possible changes in the nearest future.

\section{Materials and methods}

GHG emissions in animal breeding are created mainly by carbon dioxide $\left(\mathrm{CO}_{2}\right)$, methane $\left(\mathrm{CH}_{4}\right)$ and univalent nitric oxide $\left(\mathrm{N}_{2} \mathrm{O}\right)$, but the causes of these emissions can be divided in several groups. 
1. Methane emissions caused by gut fermentation of cattle and other ruminant type farm animals.

2. Direct methane and nitric dioxide emissions. The intensity of their production depends on the technologies of farm manure collection, storage and usage as well also on the climatic conditions.

3. Indirect nitric oxide emissions in the places of farm manure collection, storage and application. These emissions are caused by ammonia evaporation and losses of nitrogen elution. The amount of these emissions depends on the way how farm manure is collected and stored.

4. Nitric oxide emissions in the pastures that are created by farm animal manure left in the pastures.

5. Nitric oxide emissions from working farm manure into the ground. They are dependent on the kind of farm manure, the applied technology, weather conditions and other factors.

6. Nitric oxide emissions from manure worked into the ground. They are influenced by the amount of nitrogen in farm manure after storage. Consequently, also this indicator depends on the kind of farm manure removal and storage, nitrogen losses at ammonia $\left(\mathrm{NH}_{3}\right)$ evaporation and oxide $\left(\mathrm{NO}_{\mathrm{x}}\right)$ forms as well as nitrogen elution from the soil.

To evaluate these emissions the methodology determined in the 2006 IPCC Guidelines is used. This methodology can be applied for calculation of methane as well as $\mathrm{N}_{2} \mathrm{O}$ emissions. However, in order to state the total value of GHG emissions the kinds of the above mentioned emissions are recalculated in $\mathrm{CO}_{2}$ equivalent. For this purpose, to recalculate $\mathrm{CH}_{4}$ to $\mathrm{CO}_{2}$, the coefficient 25 is used, but to recalculate $\mathrm{N}_{2} \mathrm{O}$ to $\mathrm{CO}_{2}$, the coefficient 298 is used [5].

\title{
Results and discussion
}

Summarising the data on GHG emissions caused by farm animal breeding and farm manure management in 2017, it was found that $73 \%$ of them are created by movement of farm animal digestive tract.

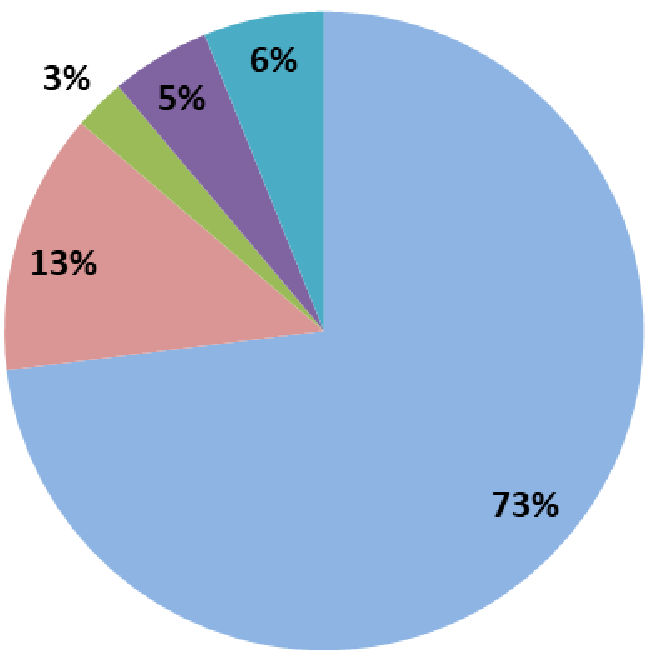

\author{
Emissions from animal gut \\ fermentation \\ - Direct emissions from farm \\ manure management \\ Indirect emissions from farm \\ manure management \\ Emissions in pastures \\ Emissions from working farm \\ manure into the ground
}

Fig. 1. Proportion of GHG emissions caused by animal breeding in 2017

The amount of methane emissions created in the digestive tract of farm animals depends on the animal breed, age, number, the quality of the animal feed and how it is balanced [6]. Still, the quality of animal feed is to a large degree dependent on the applied technology and the existing weather conditions. Therefore, at present great attention is paid to feeding balanced feed mixtures. For instance, it has been stated that increasing the amount of starch in the ration of feed for milk cows methane emissions reduce by $17 \%$ [6].

Nevertheless, correct farm manure management offers much more possibilities to reduce direct and indirect GHG emissions. The most important emission reduction measures are described in special literature [7-9]. Still, according to our recent research [10], in Latvia greater attention should be paid not only to building of new and modern animal farms, but also to timely removal of farm manure, usage of qualitative litter, application of liquid manure chemical and biological additives and implementation of other measures that do not require large expenses. 
With modernisation of the milk production technologies and increase in the milk yields the number of milk cows and their pasturing gradually decrease, and it decreases also GHG emissions. But at the same time the number of beef cattle, which stay mainly in the pastures, increases sharply. For this reason, calculating in total, there is no hope that the usage of pastures will decrease in future.

Increased GHG emissions can be caused also by working farm manure into the ground. Today the technologies of farm manure spreading and working into the ground improve fast; therefore, there are great potential possibilities of reduction of $\mathrm{N}$ losses.

Variations of direct GHG emissions in breeding different farm animals are summarised in Figure 2.

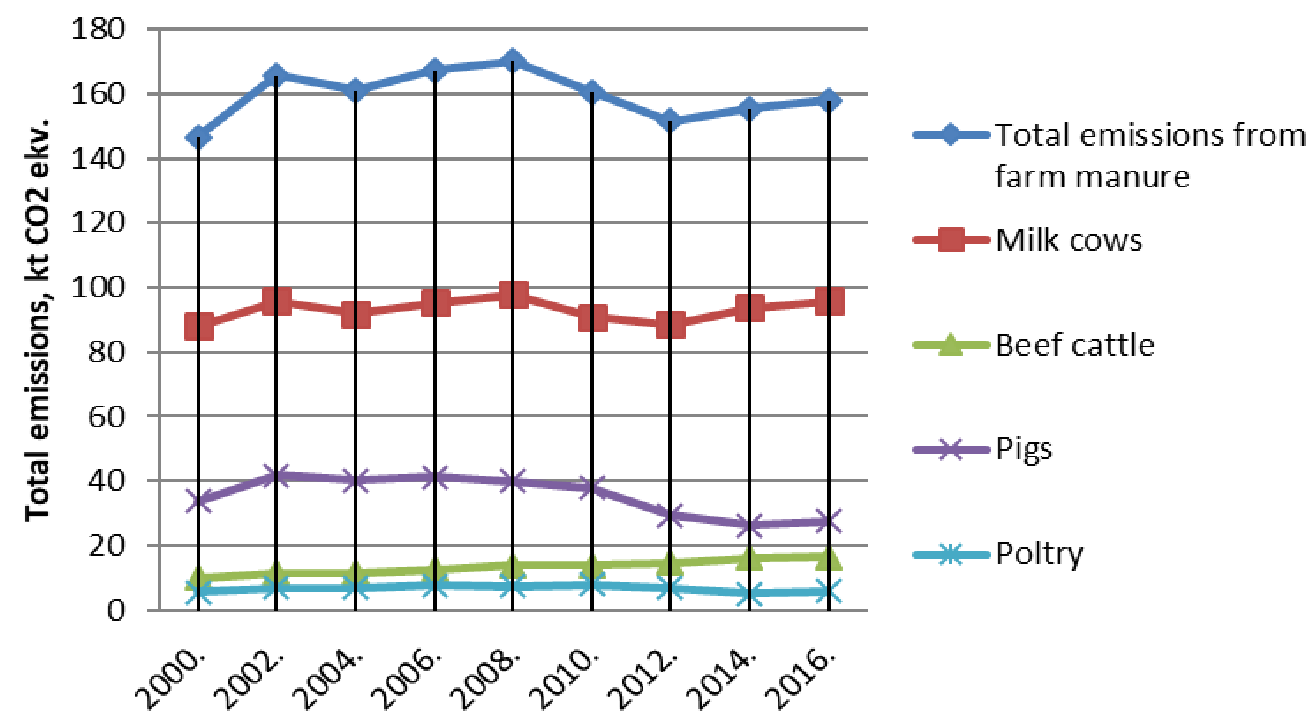

Fig. 2. Variations in direct GHG emissions caused by animal breeding in Latvia from 2000 to 2016

Approximately $60 \%$ of farm manure management GHG emissions are created by breeding milk cows, their calves and young stock. Besides, in the period of time included in the research the level of these emissions has been comparatively stable: it has changed in the frame of $\pm 8 \%$, and there have been different reasons for these variations. They are partly related to two crises in milk farming in the last ten years, when the number of milk cows decreased and transition from production of litter farm manure to liquid farm manure was gradually implemented.

In turn, stable increase in GHG emissions has been observed in breeding beef cattle. In the period of time from 2000 to 2016 in this branch of agriculture the number of farm animals has increased approximately 20 times and the same is the increase in GHG emissions, reaching $6.4 \mathrm{kt} \mathrm{CO}_{2}$ equivalents in 2016. Whereas in pig breeding the situation has been unstable. In the period of time under discussion the number of pigs has changed several times due to the economic conditions, but in recent years it has been influenced also by the African swine fever. Therefore, the maximal GHG emission level in pig breeding had stabilized from 2002 to 2008 reaching $40 \mathrm{kt} \mathrm{CO}_{2}$ equivalents. But in the recent years it has decreased to $27.5 \mathrm{kt} \mathrm{CO}_{2}$ equivalents.

There have been also slight changes in poultry farming, as in this branch in 2012 the requirements for poultry welfare were changed and there were also problems of economic character. Nevertheless, the GHG emissions created by this branch are comparatively small (within the frame of 5.5-8.0 $\mathrm{kt}^{\mathrm{CO}_{2}}$ equivalents) and therefore they influenced the total level of emissions created in animal breeding only slightly.

Figure 2 shows also the variations of total direct GHG emissions from 2000 to 2016. They also have irregular character of changes as they are influenced by all reasons of the changes in GHG emissions that are described above. The total value of direct GHG emissions is approximately $160 \pm 10 \mathrm{kt} \mathrm{CO}_{2}$ equivalents and during the recent years there is a tendency for them to grow slightly. 
Variations of separate kinds of GHG emissions related to farm manure management are shown in Figure 3.

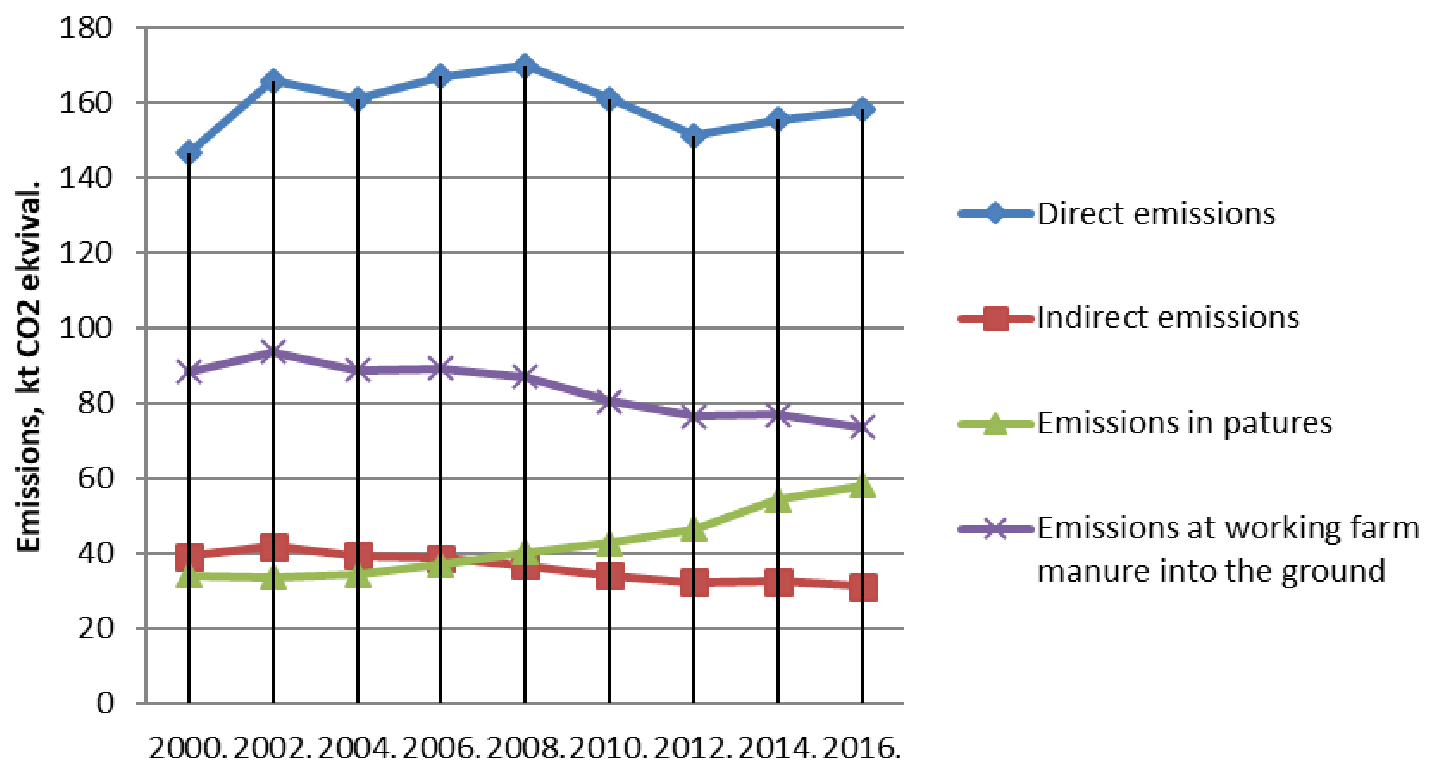

\section{Fig. 3. Variation dynamics of separate kinds of GHG emissions created in farm manure management from 2000 to 2016}

The figure shows that the greatest part of GHG emissions is created by farm manure management direct emissions. The dynamics of their variations are described above. Direct farm manure emissions are created by methane emissions and nitric oxide emissions (9.10). Our calculations show that the methane emission factor that characterises these emissions from one milk cow has increased almost three times (6.4-17.3 $\mathrm{kg} \mathrm{CH}_{4}$ ) from 2000 to 2016 and it is caused mainly by the increase in the proportion of liquid farm manure as well as by the increase in animal productivity. The system of liquid farm manure has the biggest methane conversion factor $(\mathrm{MCF}=0.1)$. Therefore, the gross energy taken by an animal increases the proportion of evaporable solid substances in animal waste contributing to the increase of methane emissions.

The second most important source of emissions in farm manure management is emissions of nitric oxide. The total amount of these emissions depends on the amount of nitrogen emitted by an animal in one year.

In the period of time under discussion indirect emissions of nitric dioxide in farm manure management have decreased by approximately $20 \%$. Reduction of these emissions was favoured by processing farm manure into biogas as well as by a number of measures to install farm manure storages in compliance with the national requirements and also by improvement of farm manure spreading and application technologies.

In turn, emissions created by digestate as organic fertiliser are registered in another category that is not related to farm manure management.

In turn, nitric oxide emissions that are created by animals in pastures have a tendency to increase and it is due to the increase of the number of beef cattle.

\section{Conclusions}

1. In animal breeding the greatest part of GHG emissions is created by the digestive tract of animals. For instance, in 2017 it created $73 \%$ of the total GHG emissions. In turn, direct methane and nitric oxide emissions that depend on the technologies of farm manure collection, storage and application as well as on the climatic conditions comprise only $13 \%$ of the total amount of GHG emissions. 
2. The highest increase in GHG emissions has been found in the period of time from 2000 to 2016 in breeding beef cattle, where the number of farm animals has increased approximately 20 times. Therefore, in $2016 \mathrm{GHG}$ emissions have reached $6.4 \mathrm{kt} \mathrm{CO}_{2}$ equivalents.

3. Approximately $60 \%$ of direct farm manure management emissions are created by breeding milk cows, their calves and young stock, but approximately $20 \%$ - by pig breeding. If no changes were made in the development of animal breeding, then in 2020 the part of direct GHG emissions from management of milk cow farm manure would increase to $65 \%$, but in 2025 - to $75 \%$.

4. From 2000 to 2017 emissions created in farm manure management in Latvia have increased by $3.7 \%$. Using the existing methodology for calculation of GHG emissions it is not possible to prognosticate reduction of these emissions. Therefore, it is necessary to introduce the emission reduction measures that are described in special literature, for instance, application of bacteriological or chemical additives to liquid farm manure. These measures should be considered in the methodology of calculation of GHG emissions.

\section{References}

[1] LR Zemkopības ministrija. Latvijas lauksaimniecība. Gada ziṇojums. 2017 (Latvia Agriculture. Annual report 2017). 180 p. [online][16.02.2019] Available at: https://www.zm.gov.lv/public/ files/CMS_Static_Page_Doc/00/00/01/10/04/fs-

01usersLinda.BirinaDesktopAA2017_lauksaimniecibasgadazinojums.pdf (In Latvian)

[2] Centrālās statistikas pārvaldes datu bāze. (Central Statistical Bureau database). [online] [16.02.2019] Available at : http://data.csb.gov.lv (In Latvian)

[3] Directive (EU) 2016/2284 of the European Parliament and of the Council of 14 December 2016 on the reduction of national emissions of certain atmospheric pollutants, amending Directive 2003/35/EC and repealing Directive 2001/81/EC. Official Journal of the European Union, L 344, pp. 1-31.

[4] Ministru kabineta noteikumi Nr.217 „Noteikumi par siltumnīcefekta gāzu emisijas vienību inventarizācijas nacionālo sistēmu" (Cabinet of Ministers Regulation No 217 "Regulation of the national system of inventory of greenhouse gas emission units") (in Latvian)

[5] 2006 IPCC Guidelines for National Greenhouse Gas Inventories. Chapter 10: Emissions from Livestock and Manure Management. $87 \mathrm{p}$.

[6] Dreijere S. Siltumnīcefektu radošo gāzu samazināšana slaucamo govju ganāmpulkos. (Reducing greenhouse gases in dairy herds ), LLKC Publishing house, 2017, 6 p. (In Latvian)

[7] Tian L., Cai Y., Akiyama H. A review of indirect $\mathrm{N}_{2} \mathrm{O}$ emission factors from agricultural nitrogen leaching and runoff to update of the default IPCC values. Environmental Pollution, 2019, pp. 300306.

[8] Reisinger A., Clark, H. How much do direct livestock emissions actually contribute to global warming? Global Change Biology, 24 (4), 2018, pp. 1749-1761

[9] Sudars R., Priekulis J., Bērziņa L., Valujeva K. Manure management systems impact on GHG emissions. /Proceedings of the 25th NJF Congress. Riga, $16^{\text {th }}-18^{\text {th }}$ of June, 2015. p.288.-291.

[10] Priekulis J., Melece L. Ammonia emissions reduction possibilities from dairy farms. Productivity of rotary parlours. $/ 17^{\text {th }}$ International Scientific Conference "Engineering for Rural Development". Proceedings, Volume 17. Jelgava, May 23-25, 2018. p.52.-56. 